\title{
Customer-Responsive Supply of Local Foods
}

\author{
Per Engelseth \\ Molde University College, Faculty of Logistics, 6410 Molde, Norway, \\ E-mail: peen@himolde.no
}

\begin{abstract}
To attain sustainable logistics in food production, shortening transport from food production source to the place of consumption, is emerging as a major topic in food supply. First literature on local food distribution is reviewed. Based on this review a single case study of local food supply in the Norwegian town of Narvik is described. The case concerns accordingly a municipality. Inquiry involves a case study including a triangulation of in-depth interviews with producers, retailers and a consumer survey. Findings provide understanding of how to define "local foods" as well as the importance of this form of food distribution. The study underpins the growing importance of this form of food distribution. It also reveals how local foods involve using complex marketing channels even though distance is small. This means that a wide range of logistics solutions is feasible. Other than the "short transport" feature, there is accordingly no clear-cut form of logistics for the distribution of local foods.
\end{abstract}

Keywords: local food distribution, logistics, market driven supply

\section{INTRODUCTION}

This exploratory study investigates features of existing local food distribution systems in Northern Norway including investigation of several tiers of suppliers and consumers taking therefore into account particularities associated with analyzing end-to-end supply chain configurations (Engelseth, 2012). This includes focus on multiple perceptions of supply purposes and therefore supply-related roles in a complex supply network. The research issue is specifically associated with developing customer-responsive supply of local foods. This implies combining a marketing perspective involving customer sensitivity, with a logistics side, involving understanding how customer satisfaction may be achieved through logistics.

Food markets are increasingly globalized (Abatekassa and Peterson, 2011). Yet globalization has also caused an opposite effect in the socio-cultural areas through production relocation including fresh foods facilitated by advances in both transport and foods preservation technology. As transport distance of major branded foods increase to retail outlets, there is also a growing trend for food retailers in developed countries to source foods locally. This is associated with the relatively affluent customers in developed country food markets seeking "quality" foods. Local foods are associated with freshness and authenticity; implying a particular form of market positioning differentiating them from mass produced foods dominating food supply in these markets. The increase in demand for locally produced foods in the supermarket and daily food shops in developed countries have marked the re-emergence of local food producers in the food chain and several studies show that there is an increase in demand for local food (Magid et al., 2002).

In developing countries, local foods still account for the dominant form of food distribution. Local foods are gaining market shares in the developed economies of the world and occupy more space on retailer shelves due to this form of branding effort (Roaldsen and Ljunggren, 2012). For example, according to Haugen Mehl (2012), there are currently between 1,500 and 1,700 local food producers in Norway. Sales of such local food producers are increased by $13 \%$ from 2010 to 2011 . It is bigger growth in the overall market than is recorded $4 \%$ increase over the same period. Furthermore, she says that the economic value of local food that was traded was 2.6 billion NOK between 2010 and 2011.

The topic of "local food" has due to recent changes in food distribution, mainly associated with increased consumer demand of quality foods that not necessarily are low in cost, therefore entered the academic discussion in recent years. There is accordingly also a need to investigate details and general features of local foods and their supply design to consumers. This includes a notion still unrealized, that local foods also entail economics of logistics through applying advanced logistics technology. This approach may be associated with large-scale local foods distribution in developing countries as the smaller volume up-market type local foods distribution in developed countries.

This case study focuses on local foods supply in developed Norwegian market. The upmarket nature of local foods supply in developed countries also implies a higher importance of the service factor associated with such supply. This implies that logistics of local foods involves a complex intertwining of goods and service elements. Risk is accordingly associated not merely with foods features such as perishability, but also with how actors network. Strategic focus on the servitization is vital in the supply of such local foods. This implies, in line with Astuti et al. (2013) a need to focus on the quality of interaction in business relationships in food chains to mitigate risk. Vilko and Ritala (2014) point to the need to adapt the mitigation of risk to service industries. Local foods supply is accordingly a type of supply that demands adaptation of logistics to industry particularities associated with food product features as well as the higher content of service associated with this type of upmarket product offering.

In this exploratory study, marketing and logistical features of local foods are investigated in the small Northern Norwegian town of Narvik. The unit of analysis is the local food supply network limited to this municipality. Academically this study is placed in the borderlines between logistics and marketing; it takes into consideration consumer and supplier preferences regarding food supply design as well as the logistics associated with these preferences. It 
investigates supply network actor preferences (including consumers), based on these observations, the study also points to logistical consequences of local food supply. This study provides accordingly theoretical development through evoking descriptive detail in in both the marketing and logistics of local foods thereby creating basis for considering how to develop such local food systems from an end-to-end perspective including intermediaries.

\section{LITERATURE REVIEW}

The general meaning of "local foods" refers to food produced close to consumers (Martinez et al., 2010). "Local foods" is a reflexive concept associated with all activities related to the method of food production and distribution constrained by geographical measures and socio-cultural emotions (Amilien et al., 2008). There is no universal agreed definition of what constitutes a "local food system". The local food system consists of three major questions: 1) how and where food is produced, 2) how food will be distributed to consumers and 3) consumer food preferences \& options (Darby et al., 2008; King, 2010). These three questions represent the epicenter of the local foods system. They are furthermore also conceptually overlapping and interdependent. Under the Consolidated Farm and Rural Development Act, as enacted by the U.S. Congress in 2008 as HR 2419, defines the term locally as 1) the locality or region in which the final product is marketed, so that the total distance that the product is transported less than 400 miles $(640 \mathrm{Km})$ from the origin of the product, or 2) the State in which the product is manufactured. This definition reflects only a geographical aspect of where food is produced and eaten, not "how and why". This geographical characterization of local foods oversees organic components of the local food system. In particular, it is assumed that local food producers use less chemicals and more natural ingredients. Therefore, environmentally friendly production methods and local food is characterized as "organic foods". The 400 mile $(640 \mathrm{~km}$.) reference is constructed based on U.S. political and geographical realities. In France, this boundary determining whether a food is locally distributed is set at $80 \mathrm{~km}$. This means that the geographical importance of local food and simplified logistics system depends on the size of a nation or a country. The main premise behind this distance-wise reference point is that the shorter the distance food travels, the more secure and safe it is (Saunders et al., 2006).

The question of how food is distributed to consumers involves focus on market arrangements that importantly include logistics resources in a defined local food system (Martinez et al., 2010). The traditional market arrangement, such as found in developing countries today, in a local food system has been a direct producer-consumer relationship, a form of marketing channel arrangement where consumers buy directly from producers at farmers' markets or producers sell through their own proprietary facilities (Dunne et al., 2011). This locality implies a heightening of reciprocal interdependencies, supply-related solutions are not planned, but negotiated. Business relationships are therefore important in local foods distribution. In a traditional setting these relationships may, however be many, since volumes are small and customers may be many. Modernizing local foods distribution implies reducing the customer base, using intermediaries to supply local foods. This is to some degree the case in local foods distribution in developed countries since these foods are not sold at traditional markets, but through retail chains. This means a simplification of logistics and increased potential for logistics planning.

Because of the constant growing demand for local food and its market potential, retailers and grocery stores increasingly carry out the distribution of local foods. Traditional and direct producer-consumer relationship have gradually been replaced by a more complex network of stakeholders including manufacturers, distributors, retailers and the consumers in a particular place; the "locals" (Dunne et al., 2011). In the middle of this complex network of relations between actors is the prerequisite for efficient and integrated supply chain and logistics performance (Deller and Brown, 2011). That is, the shorter the supply chain and high performance of the logistics system in the local food system leads to higher profit margins for producers and higher satisfaction for consumers by offering fresh foods. The third main component of the local food system is the customer of local foods. Since there is no universal agreed definition of what "local foods" are consumers are left to decide what local food means to them (GRACE, 2014). Consumers' preferences and perspectives of what constitutes "local foods" are dependent on their socio-cultural backgrounds, attitudes and behaviors (Zepeda and Li, 2006). The socio-cultural background refers to consumers' emotional attachment to local people and a desire to support the local economy and improve the local environment (Zepeda and Levit-Reid, 2004) and membership in environmental advocacy group (Brown, 2003). According to Wolf et al., (2005), the typical buyers of local foods in developed countries are women, college educated and those with above average incomes. This market segment also allows food distributors to precisely segment this target market in their branding and promotion. This marketing effort must also be followed up with trustworthy logistics systems and traceability to convince consumers that the quality foods actually are what they are promoted as.

Every consumer has their own reasons for buying local foods although there are differences in the understanding of what "local" means. Three competing issues explain why consumers shop locally produced foods. These issues are: 1) food security and self-sufficiency, 2) protection of local markets, and 3) socio-cultural self-identification. The first issue concerns food safety as linked to consumer ease access to desirable properties of foods that they should buy and increase their confidence (Zepada and Li, 2006). On the other hand, food safety related to "when all people's physical, social and economic access to sufficient, safe and nutritious food that meets their dietary needs and food preferences for an active and healthy life" (FAO UN, 2003). There is a technical aspect and a consumer behavior aspect of food safety. The consumer behavior aspect, since it is economic, may involves what may be conceptualized as "food quality" issues. Self-sufficiency involves positive consumer confidence in quality supply that in turn positively affects consumer food a safety perception. Secondly, the local food system is viewed as sustainable since it goes to small and permanent networks that help to protect community health and stimulate local economies. This issue assumes that local manufacturers not only use 
environmentally friendly production, but they also bear a social responsibility to protect the community's health. Thus, consumers are rational and they are completely aware of the advantages of a local food system. The stronger the local economy is sustainable local food system, the healthier the community will be. The third point is related to a sociocultural perspective; a socio-cultural expression of an individual or a group of people (Rusaanes and Hjortland, 2000). The process of globalization is, however, changing this expression; an international convergence of sociocultural self-identity through a flow of ideas, goods and services. Global food brands and the globalization of ethnic foods such as pizza, kebab and sushi are examples of this globalizing of social-cultural identity. Consumers then buy locally produced foods in a globalized market context because of their self-identification as symbolized by the nature and forms of locally produced food (Roaldsen and Ljunggren, 2012). They choose local foods as a statement of preference over globalized or national food product brands. For example, in an area where fish is the predominant type of food, cooking local fish producers in many different forms. People eat fish and it could be the cultural identity of the people in this area. Thus, people buy locally produced fish foods because eating fish is their culture and to buy locally produced fish food is a way that matches their culture. Moreover, this assumption states that social status plays a significant role in increasing consumer motivation and buying locally produced foods. This issue also points to a market opportunity; local foods may also be distributed globally. However, this issue is not considered in this research focusing on short transport distances of foods.

Local food producers can be defined in accordance with different parameters ranging from the nature of business ownership, methods of production, the size of a business, availability, nature of end products and its relationship to place (Kvam and Magnus, 2012). One of the classic definitions of who local food producers are involves that food manufacturers process and sells its products in a given geo-political boundaries are termed "local foods producers". Marsden et al. (2000) refers to these characteristics as "relationship to place". However, this definition has been disputed by other factors. For example, Low and Vogel (2011) introduced local ownership, size and scale including marketing channels as the most important defining factors for conceptualizing local producers. According to this view, local food producers (farms) are owned by local people. Consequently, local food producers are small and medium scale companies.

Final products are marketed directly to consumers or through intermediaries marketing channels (Martinez et al., 2010; GRACE, 2014). These characteristics of local food producers are not universal. For example, Deller and Brown (2012) characterize local food producers based on "production techniques" they use and by features of their products; "commodity" versus "non-commodity" products. These characteristics of local food producers are neither well defined nor systematically oriented to define local food producers. The common assumption of food production method is that local producers are micro or medium scale and their market size is limited within a given geographic boundaries and they use natural ingredients; they are "organic producers". Of these local food producers are methods for producing mostly "related to sustainable agriculture, while the global industrial food system is dependent industrial agriculture" (GRACE, 2014). Defining local food producers based on the content of the final product in a dichotomous way (commodity versus noncommodity crops), facing other forms of local producers and their end products.

Marketing channels are applied within marketing theory to describe the nature of market arrangements where manufacturers distribute and sell their products to consumers (Halweil, 2002). This description applies the channel metaphor to describe a long-linked form of supply involving sequential interdependencies, typical of physical distribution (Thompson, 1967). The marketing channel is distinguished from the "supply chain" concept in that it focuses on the exchange economy including the important transfer of product title. The supply chain is focused on the production economy and involves the logistics function. In local foods systems production and exchange economies are intertwined in a manner that is distinguishable from more far stretching geographically defined distribution structures (Hammervoll, 2014). This involves how production and exchange are configured. Production involves how value creation through time, place and form transformation takes place while exchange involves transactions of product ownership. As previously indicated, local foods implies more manual information exchange due to increased importance of personal ties. This also implies that local food is increasingly reciprocally interdependent since logistics solutions are negotiated in individual rather than planned in detail. People and developing exchange skills are vital in developing the efficiency of local foods distribution.

In local marketing channels the nature and properties of market arrangements in the local food system differs from the traditional and global industrial agriculture. The main characteristics of the local food system in the market scheme is short distribution distance between producer and consumer, few or no intermediaries involved in the packaging, transportation and sales and the existence of primary market channels (GRACE, 2014; Flaten et al., 2007). While market regulation in the global industrial agriculture is characterized by long distance between producers and consumers, complex web of intermediaries, interactions, complex and sophisticated packaging and hightech transport (GRACE, 2014). Accordingly marketing channels in a local food system is a simplified network supporting interaction between producers, potential intermediaries and consumers. While marketing channels in the global industrial agriculture has a complex web of relationships between producers, intermediaries and consumers. In fact, there is no direct relationship between producer and consumer in the global industrial agriculture. In this simplified network, the actors have face and personality. An important aspect of such local foods networks is accordingly that supply actors network and develop skills in this interaction based on knowing each other.

Producers of goods and services will only be able to obtain access to the market through marketing channels that create exchange that is the foundation of production through tiers of supply network actors. There are two main forms of marketing channels in the local food system as local food 
manufacturers use to reach their customers: 1) direct-toconsumer, and 2) use of intermediaries. Both these forms may be organized in a range of manner, with the use of intermediaries naturally involving a higher degree of network complexity. Direct-to-consumer marketing channel exists when there is a direct relationship between producer and consumer without the interference of intermediaries in packaging, distribution and sales. The marketing channel may be organized through local markets (eg. Farmer's market), manufacturers' sales offices, community-based units sold, localized exhibition program and other mechanisms that manufacturers use to sell their products directly to consumers such as consumers coming to the farm or to fishermen (Bioforsk, 2012).

Intermediaries in marketing channels create a bridge between producers and consumers, a simplification of marketing efforts for the food raw materials producer. In most cases, manufacturing, packaging and transportation activities handled by local food producers themselves. These intermediary roles are limited only to local producers selling agent. Unlike intermediaries in the global industrialized food system, intermediaries in the local food system are rarely large businesses. Local manufacturers often supply their products directly to localized food "hubs" which is a "central location where local manufacturers distribute their products through one or more entities" (GRACE, 2014). In some cases, some local manufacturers use these two types of marketing channels either alternatively or in combination of ways such as combining private distribution systems with more professional ones.

Efficient transport and quality delivery of local foods with high form quality is dependent on quality logistics both inn relation to costs and customer satisfaction. Foods supply is associated with "customer value objectives" that includes traceability (Engelseth et al. 2014). Traceability ensures customer perceptions of authenticity of the foods, and in local foods chains traceability is managed through manual systems. Logistics activities are designed to ensure efficient flow of goods from origin to consumption place. It includes the integrated flow of goods, information and funds between actors in the supply chain (Lambert et al. 1998, Christopher, 2011). There are coordinating material flow and information flows to meet customer needs. Quality logistics provides benefits both in terms of reduced costs, increased efficiency, increased commodity value and efficient use of resources. Logistics systems at local level in local food production are less complex since in the more limited geographical area there are fewer actors and less resources involved in the local foods logistics system. Furthermore, closeness indicates cluster tendency that also involves closeness in exchange interaction allowing more manual exchange procedures such as interpersonal communication. This increased manual, and therefore necessarily human interaction, indicates heightened reciprocal interdependencies that also indicate uncertainties and means for responsive supply in local foods logistics systems.

The general characteristics of the local foods logistics system are short lead times and low transport costs. Short lead-time helps to meet end customer needs and provide services faster with lower costs. However, there is no clear answer how short the transport distance food can be to be termed as "local". Parker (2005) defines that the short food supply chains are chains where geographical distance and/or the number of the intermediates are reduced. Yet the boundaries and issues of the local food supply networks may vary, they are dependent on the actors involved, their goals, their areas and their problems (Blanquart et al., 2010).

When it comes to the number of intermediaries, this is dependent on the marketing channel strategy (their longterm thinking) used by local food producers. For example, some local food producers sell their products directly to the customer (in this case there are no retailers involved), some selling to supermarkets through a complex dealer/retailer network and some use a mix of direct and indirect marketing channels (few retailers involved). Therefore, the type of marketing channel that is used by local food producers and the number of intermediaries involved in, since it impacts on "network complexity" (Christopher, 2011) defines also the efficiency of the logistics system in the local food chain. According to Aghazadeh (2004), an efficient logistics system needs to deliver the right product, in the right quantity, in the right condition, at the right place at the right time, for the right price. This common understanding of logistics quality entails to produce and deliver Just-in-time (JIT) to satisfy the demand indicating potential for Lean principles in local foods supply development. Distribution of local food products in the logistics system may have some logistical quality advantages, for example, on-time deliveries, easy handling, fast delivery, low degree of waste and less need for storage, experiencing sales units. (Harrison and Van Hoek, 2011, pp. 221-235).

Coordination and integration between all local actors (producers, distributors and consumers) and other stakeholders is essential to improving market and increase consumer interest by building a beneficial food chain at the local level. Integration in the food supply chain involves a network of different more or less coordinated actors. Coordination is dependent on internal, external or electronic integration of logistics resources, both physical and knowledge-related. Integration has many advantages, also in the case of local foods, such as providing a high level of customer service, meet customer needs, reduce logistics costs, improve product availability, and efficient supply products with "just-in-time" lean type supply (Harrison and Van Hoek, 2011. p. 255-262). This coordination and integration makes it possible to ensure a coordinated distribution of local foods and facilitate the integration of food distribution from the collection centers to large-scale food distribution channels (Boson, 2010; Amilia et al., 2008). Therefore, the local logistics system is not just a system where local food products are transported and distributed, but there is also an adapted information and financial flow configuration from producers to consumers and vice-versa representing distinct features of an "exchange" economy supporting a distinct form of "production" (including all forms of supply processes). Food product traceability is a requirement in local foods distribution in developed countries since this form of distribution is associated with up-market products.

\section{METHOD}

In this, an explorative phase of research probing into characteristics of local food supply networks though a case study of goods supply (Kähkönen, 2011). The case study 
research methodology involves applying multiple complementary approaches (Yin, 2003). It was chosen to investigate what constitutes of marketing channels actor preferences to local food distribution. The starting point of this exercise is that it is claimed that local food producers' market share has increased in recent years due to: 1) consumer perception, understanding and their socioeconomic background, 2) manufacturers marketing strategy, 3) perceptions of retailers and 4) improving logistics efficiencies of local food producers. This project attempts to look at the above four points and answer questions related to why and how local food producers market share increases relative to the globalization process, especially in the food industry. Three different questionnaires for these three actor types in local food network in Narvik were developed: one for the producer, one for retailers, and another for consumers. The interview guides have a different theme and parts such as general questions on local food production; local foods marketing development, transport and logistics system, processing of local food, marketing, sales, distribution and social contributions. The questionnaire applied for consumers consisted of a mix of both open and closed questions. Open questions have aimed to collect primary data for descriptive (qualitative) aspects of research aimed at understanding the perceptions and feelings of consumers, stores/retailers and manufacturers about the local food system. It has also helped to get additional information out of the response options provided in advance and has given the respondent an opportunity to respond freely (Johannessen et al., 2009. pp. 249-262). Closed questions also contained a mixture of multiple choice questions, "dichotomous" questions, interval scaling and comparative ranking questions to collect data for analysis (quantitative) aspects of the project with the objectives of understanding the trends and future of local food.

The study was conducted in the municipality of Narvik because the one of the authors lives there and accordingly knows the area as well as that such a study in this area has never previously been conducted. The project took three locations in greater Narvik municipality. These are Ankenes (suburb), Bjerkvik (village about 30 minutes driving from Narvik) and Narvik city center. From these places, eight retailers were selected through a simple random sampling technique and 100 consumers informants selected randomly. Table 1 provides an overview of informant. Three food producers located in Narvik were selected: 1) Stenovnsbakeriet AS (bakery), 2) Fiskehallen AS (seafood producer), and 3) Kuraas AS (meat producer: www.kuraas.no) were selected.

Table 1 List of informants

\begin{tabular}{|c|c|c|c|c|}
\hline No. & Location & Retail shop & Interviewed customers & Local food producers \\
\hline 1 & Ankenes & $\begin{array}{c}\text { Kiwi } \\
\text { Coop Prix }\end{array}$ & Kuraas AS \\
\hline 2 & Bjerkvik & $\begin{array}{c}\text { Rema 1000 } \\
\text { Rimi }\end{array}$ & 25 & Steinovnsbakeriet AS \\
\hline 3 & Narvik & $\begin{array}{c}\text { Coop Prix } \\
\text { ICA } \\
\text { Coop Obs } \\
\text { Rema 1000 }\end{array}$ & 50 & Fiskehallen AS \\
\hline Total & 3 & 8 & 100 & 3 \\
\hline
\end{tabular}

\section{DIFFERENT PERCEPTIONS OF LOCAL FOODS IN THE CHAIN}

\subsection{Consumers of Local Foods}

$63.75 \%$ of the respondents are women and $36.25 \%$ are men. $22.5 \%$ are under the age of 30 , while customers from $30-49$ and from $50-69$ years is $70 \%$ (35\% each). The remaining $7.5 \%$ of the customers are over 70 years old. In addition, the survey shows that the majority of women $41.2 \%$ who buy local food are between 50-69 years, while the majority of men $44.8 \%$ who buy local food is between 30-49 years. Most of the respondents have secondary education consisting of nearly $32.5 \%$ of the total respondents. Only $17.5 \%$ of respondents are university / college up to 4 years of education levels. The majority of $48.75 \%$ of the respondents earn between 300001 to 450000 NOK annually. Customer survey shows that the second highest percentage $22.5 \%$ in group $151001-300000$ million and consequently the $15 \%$ interval average income 450001 to 600000 annually. Only $2.5 \%$ of respondents have earning more than 600,001 per year. The remaining respondents $11.25 \%$, have earning under 150,000 per year. In terms of cultural orientation considers most $61.25 \%$ of the respondents themselves as "moderate cultural conservative" while the next largest group $26.25 \%$ of the respondents consider themselves "not as such cultural conservative". Very few, $3.75 \%$ of the respondents consider themselves as "very strong cultural and conservative", while $8.75 \%$ of the respondents consider themselves as "strong and culturally conservative". $48.75 \%$ of the respondents born and raised in Narvik Municipality. Respondents who have lived in Narvik municipality in the past five years, 15 years and 30 years were $25 \%, 15 \%$ and $11.25 \%$ of the total respondents. The following table provides the outcome of the consumer survey: 
Table 2 Consumer survey responses

\begin{tabular}{|c|c|}
\hline \multicolumn{2}{|l|}{ Question 1: What is a local food? } \\
\hline 1. Food produced in Narvik & $38.75 \%$ \\
\hline 2. Food produced in Norway & $33.75 \%$ \\
\hline 3. Food produced within a $160 \mathrm{~km}$ radius & $21.25 \%$ \\
\hline 4. Food produced within a $640 \mathrm{~km}$. radius & $6.25 \%$ \\
\hline \multicolumn{2}{|l|}{ Question 2: What characterizes local foods? } \\
\hline 1. Healthy, fresh \& taste better & $52.5 \%$ \\
\hline $\begin{array}{l}\text { 2. Produced in accordance with } \\
\text { environmentally sound methods }\end{array}$ & $31.25 \%$ \\
\hline 3. Safe to eat and ecological & $16.25 \%$ \\
\hline 4. Stimulate local economy & $16,25 \%$ \\
\hline \multicolumn{2}{|l|}{$\begin{array}{l}\text { Question 3: How often do you purchase local } \\
\text { foods? }\end{array}$} \\
\hline 1. Daily & $21.5 \%$ \\
\hline 2. A couple of times a week & $71.25 \%$ \\
\hline 3. Seldom & $7.5 \%$ \\
\hline \multicolumn{2}{|l|}{$\begin{array}{l}\text { Question 4: What type of local foods do you } \\
\text { purchase most often? }\end{array}$} \\
\hline 1. Fruits and vegetables & $24 \%$ \\
\hline 2. Bakery products & $19 \%$ \\
\hline 3. Meats & $23 \%$ \\
\hline 4. Seafood & $23 \%$ \\
\hline 5. Dairy products & $11 \%$ \\
\hline \multicolumn{2}{|l|}{$\begin{array}{l}\text { Question 5: How has your use of local foods } \\
\text { changed the past years? }\end{array}$} \\
\hline 1. Increased & $39 \%$ \\
\hline 2. Unchanged & $50 \%$ \\
\hline 3. Reduced & $11 \%$ \\
\hline
\end{tabular}

\subsection{The Local Producers}

Local food manufacturers produce different types of foods. For example, the local food producers who are the subject of this study produce meat and meat products, fish and fish products and seafood and bakery products (lefse (sweet flatbread), flatbread, bread). Some of the local food producers use raw materials purchased locally, while some of them are also using raw materials sourced from areas outside the region. None of the manufacturers uses raw materials from abroad. In this qualitative inquiry, the manufacturers were asked about "To what extent is the method of production according to the following factors (chemicals used, carbon dioxide (CO2) emissions, the degree of labor-intensive technology used and the extent of ecologically friendly waste management system is used)". Commonly no form of chemicals use, including low carbon dioxide ( $\mathrm{CO} 2)$ emissions, was detected. Only one of the producers answered that they use labor-intensive methods of production technology. Manufacturers use ecologically friendly waste management systems a using manufacturer ranging from "some extent" to "a very high degree".

In addition, some manufacturers produce organic foods and some of them produce a mixture of organic and non-organic foods.

The distribution strategy is considered to be one of the pillars of local food producer's success. Local Food
Producers use a mixture of different exchange processes types to contact the customer (retailer) and end-user. Usually you use the telephone, newspaper, poster in the shop, sponsorship of sports clubs/associations etc. In terms of coverage areas, some manufacturers sell their products only in Narvik, while the other manufacturers sell their products in Narvik municipality and adjacent municipalities. The survey shows that local food manufacturers use different marketing strategies in local food production. As for market position, some manufacturers consider themselves as niche players. Some develop a marketing strategy to enter this market and then expand. In addition, some of the local food producers view themselves as market leader as well as market follower, waiting to copy a market leader.

\subsection{Retailers}

The survey shows that retailers have a similar perception of local food showing increasing interest. The following questions were posed retailers: 1) How do you describe local food producers and 2) what does it mean that food is produced locally?" The responses indicate that respondents (stores) define local food and local food producers as few in number, small in size, good quality, made by manufacturers within the municipality and has decent return scheme. The stores/merchants often sell local foods such as meat and meat products, fish, fish products and seafood, dairy products, vegetable products, fruit products and baking. In addition, studies show that the three main reasons that retailers sell local foods are 1) "because there is a growing demand for locally produced food", 2) "because local food products create high profits for retailers", and 3) "because the stores have a good cooperation with local food producers".

Integration and collaboration are stated as very important and key role in the food chain. The responses show that cooperation between local food producers and retailers are tight including monitoring, information sharing and common goals (profit maximization through social services). Most people describe the relationship between the retailers and local food producers as a good working relationship. The employment contract between most shops and local food producers is done at the central retail chain level and that means quality, quantity of product, price, delivery arrangements and monitoring mechanisms. The interviews also included questions on packaging and transportation activities: "Who is responsible for packaging and transport activities?" Some local food producers say that packaging and transportation activities handled by themselves and some say that the activities are outsourced to another third party. Among the respondents (retailers), only two stores described having activities related to packaging and transport. Regarding the effectiveness of local food producers' logistics system, $23 \%$ of the retailers expressed that the logistics system in local food producers are very effective, $46 \%$ said effective and $31 \%$ said moderate. None said it was outright poor.

\section{ANALYSIS}

This case study attempts to explore and thereby develop theory help explain why and how local food producers' market share has increased in recent years. 
Firstly, the US local food system definition does not match Norway; much smaller country where people have a more precise concept of "local" as closer. Respondents, however, also perceive local food not only in relation to geography, but also in terms of production quality. Consumers think that local food producers using local and organic ingredients and are safer to eat, fresh and has good taste compared to national or globally branded foods. The three main reasons that consumers buy local food are indicated: 1) " local food is safer, fresh and has good and distinctive taste", 2) "the raw materials are mainly local and organic production or based on organic ingredients" and 3) "the proximity of the production process and the food is locally produced". $89 \%$ of respondents, accordingly, either increased or maintained their consumption of local food over the last years.

Local food producers use a variety of marketing channels configurations. The findings suggest that local food producers are able to identify their market position and develop market strategies based on existing conditions in order to increase their market share. Local food producers use different distribution methods to meet the steady increase in consumer demand and to establish flexible and effective cooperation with retailers. Some of the methods are: own distribution, joint distribution and distribution of products through wholesale distribution. Moreover, local food producers enjoy a stable and fast delivery service through retailers. Almost all retailers express that local food producers react very fast on the orders of foods. This suggests that local food producers have a great advantage in methods of distribution and delivery service. They have short delivery time and frequency, efficient delivery, short lead times and easy ordering procedures. The closeness in distribution supports a highly reciprocal and efficient manual logistics of smaller food qualities. The three main reasons that retailers sell local foods and work closely with local food producers are: 1) a growing demand for locally produced foods, 2) local food products create high profits for retailers, and 3) retailers have a good cooperation with local food producers.

To build an effective business relationship includes monitoring, knowledge and information sharing and common goals. This is one of the most important factors for increasing local food producers market. In addition, producer cooperation is important for the development of production and sales. Not only employment, but also the packaging and transportation activities are very important to engage the stores/merchants in the local food system. $69 \%$ of the retailers say that the logistics system in local food producers is effective. Thus, in addition to perceptions of quality food form features, it is true that efficient logistics and transport system can also be one of the main reasons for the increase of local food producers market.

Local food manufacturers' reported through interviews that sales revenues have increased in recent years. This success has led to that local food producers envision further increase in sales and market share. Further improvement in food manufacturing and logistics should sustain this vison by improving their method of production as well as the logistics systems. Logistics, production and traceability together technically support consumer perceptions of high quality of the local food products limiting consumer price sensitivity. Logistics and production impact on quality; the product time, place, form and cost features, all features of the production economy. Traceability provides information creating a sustainable consumer preference for local foods; a feature of the exchange economy. The increase of local food producers' market share has positive social impacts. In general, these impacts an environmental, social and economic benefit to the local community by increasing local employment, increase tax effort to the management units as well as providing social services and by protecting the local environment. Thus, the increase of local food producers' market share resulting from strategic and conscious effort or endogenous factors of local food producers and it also has unique social effects on lifestyle and well-being of the community. This indicates that local foods are an ethically sound manner of food supply.

\section{CONCLUSION}

The study indicates that the marketing and logistics of local foods are unsurprisingly closely intertwined. In local foods distribution, due to the proximity of actors, and the small size of these relatively simple networks, this becomes easier to reveal. Local foods thus also are a good empirical setting to study logics in a working micro-system as opposed to computer-based simulation. There is therefore unsurprisingly no clear-cut mode of logistics associated with local foods distribution other than transport distances are short. The distinguishing feature, low network complexity and proximity, doesn't not in the case reveal variation in logistics as opposed to larger scale distribution. Local foods are varied, some are manufactured, and others are fresh. Some are very perishable, seasonal, while others that are processed may be stored. The logistics of local foods is accordingly adapting mainstream logistics to the logistics of short distances. Logistics solutions are suggested dependent on product and network characteristics. This hypothesis is suggested tested in future investigation, such as a market survey. Furthermore, the study reveals that strategic development of local foods needs to design a manufacturing and logistics system that sustains consumers' positive attitudes to local foods. One such measure would be to use traceability systems (Engelseth et al., 2014). Local foods are supplied through a supply network that consists of actors closely located to each other. These points to the strategic importance of these small firms' possibilities in developing reciprocal dependencies in exchange processes to reap benefits associated with agility producing responsive supply.

An upcoming research issue would be to consider manufacturing and logistics technology; technical resources in change. This study would indicate to what degree local foods may gradually become the dominant form of food supply. Since local foods are still associated with premium quality consumers will expectedly tolerate higher costs of such products when their origin was properly documented. Furthermore, the retail chains need to make strategic decisions of prioritizing such distributions chains. Future study may also include perceptions of local foods at a strategic level in retail chains who are centrally organizing purchasing for the main volume of goods sold in supermarkets. Finally, it is also suggested that case study be directed to developing an adapted framework associated with traditional large-scale foods distribution in developing 
countries. This research should aim at increasing both the quality as well as profitability of such forms of food supply; an adapted form of "modernization" that involves information flow process automation while simultaneously increasing networking skills of actors to enhance quality associated with reciprocal interdependencies inherent to local foods networks.

\section{ACKNOWLEDGEMENT}

This paper is written based on the empirical findings of the thesis work from 2014 by Blen Delelegne when she was a student at Narvik University College in Norway.

\section{REFERENCES}

Abatekassa, Getechew and Peterson, H.C., (2011), Market Access for Local Food through the Conventional Food Supply Chain. International Food and Agribusiness Management Review, 14(1), pp. 63-82.

Aghazadeh, S.-M., (2004), Improving Logistics Operations Across the Food Industry Supply Chain. International Journal of Contemporary Hospitality Management, 16(4), pp. 263-268.

Amilien, V., Schjøll, A. og Vramo, L.M., (2008), Forbrukernes forståelse av lokal mat. Statens Institutt for Forbruksforskning. Oslo, Fagrapport nr. 1-2008.

Astuti, R., Marimin, Machfud, Arkeman, Y., Poerwanto, R. and Meuwissen, M.P.M. (2013), Risks and risk mitigations in in the supply chain of mangosteen: A case study. Operations and Supply Chain Management, 6(1), pp. 11-25.

Bioforsk, (2012), Nyhetsbrev Fra Kompetansenettverket for Lokalmat i Nord-Norge [Online]. Available in: http://www.bioforsk.no/ikbViewer/Content/100543/ Matlyst\%20nr.\%202\%202012-web.pdf. Accessed: 24.03.14.

Blanquart, C., Gonçalves, A., Kebir, L., Petit, C., Traversac, J.-B. and Vandenbossche L., (2010), The Logistic Leverages of Short Food Supply Chains Performance in Terms of Sustainability. $12^{\text {th }}$ World Conference on Transport Research. Lisbon, Portugal.

Brown, C., (2003), Consumers' Preferences for Locally Produced Food: A Study in Southeast Missouri. American Journal of Alternative Agriculture, 18(4), pp. 213-224.

Christopher, M., (2011), Logistics \& Supply Chain Management, Pearson Education Limited, Edinburg Gate UK.

Darby, K., Batte, M. T., Ernst, S., Roe, B. (2008), Decomposing Local: A Conjoint Analysis of Locally Produced Foods. American Journal of Agricultural Economics, 90(2), pp. 476-486.

Deller, S. and Brown, L., (2011), Local Foods and Community Economic Growth and Development. Paper prepared for the Department of Agricultural and Applied Economics, University of WisconsinMadison, USA.

Deller, S. and Brown, L., (2012), Thinking About the Economic Impacts of Local Food System [Online]. Available http://wilocalfood.files.wordpress.com/2012/02/2012 -wlfs-thinking-about-the-economic-impacts-of-localfood-systems.pdf (Accesed: 18.04.14).

Dunne, J. B., Chambers, K.J., Giombolini, K.J. and Schlegel, S.A., (2011), What does 'Local' mean in the Grocery Store? Multiplicity in food retailers' perspectives on sourcing and marketing local foods. Renewable Agriculture and Food Systems, No. 26, pp. 46-59.

Flaten, O., Veidal, A. og Svennerud, M., (2007), Bondens Marked - En Attraktiv Markedskanal for Nyskapende Nisjeprodusenter? Resultater fra en Spфrreundersфkelse. Resultater fra en spфrreundersфkelse. Norsk Institutt for Landbruksøkonomisk Forskning (NILF), rapport 2007 (4). Oslo.

Engelseth, Per (2012), Modelling Transformations in a Complete Fresh Food Value Networks. In Jodlbauer, H., Ohlhager, J., and Schonberger, R.J. Modelling Value, Selected papers of the $1^{\text {st }}$ International Conference on Value Chain Management. Physica Verlag (Springer), Berlin.

Engelseth, P., Wongthatsanekorn, W., Charoensiriwath, C., (2014), Food Product Traceability and Customer Value, Global Business Review. 15(4 suppl.), pp. 87S-105S

FAO UN: Food and Agriculture Organization of the United Nations. (2003), Trade Reforms and Food Security: Conceptualizing the Linkages. FA OUN Commodity and Trade Division. Rome.

GRACE. (2014) Local \& Regional Food Systems [Online]. Available in: http://www.sustainabletable.org/254/local-regionalfood-systems. Accessed: 24.02.2014

Halweil, B., (2002), Home Grown: The case for local food in a global Market. World watch Paper 163 [Online]. Available in: http://library.uniteddiversity.coop/Food/Home_Grow n-

The_Case_For_Local\%20Food_In_A_Global_Marke t.pdf. Accessed: 14.04.2014

Hammervoll, T., (2014), Service provision for co-creation of value: insights from exchange- and production economy perspectives. International Journal of Physical Distribution and Logistics Management, 44(1/2), pp. 155-168.

Harrison, A. and Van Hoek, R., (2011), Logistics Management \& Strategy: Competing Through the Supply Chain. 4 ed., Financial Times - Prentice Hall, Harlow UK.

Haugen Mehl, S., (2012), 1700 norske lokalmatprodusentar [Online]. Available in: http://www.nationen.no/tunmedia/1700-norskelokalmatprodusentar/. Accessed: 14.03.2014

Johannessen, A., Kristofferson, L. And Tufte, P.A. (2009), Forskningsmetode for Økonomisk-Administrative fag. Utg. 2. Abstrakt forslag as, Oslo, Norway.

Kähkönen, A. K. (2011), Conducting a case study in supply management. Operations and Supply Chain Management, 4(1), pp. 31-41.

King, R. P., Hand, M.S., DiGiacomo, G., Clancy, K., Gomez, M.I., Hardesty, S.D., Lev, L. and McLaughlin, E.W., (2010), Comparing the Structure, 
Size and Performance of Local and Mainstream Food Supply Chains. USDA ERS Report Number 99.

Kvam, G.-T. og Magnus, T., (2012). Vekststrategier for Lokale Matbedrifter. Norsk Senter for Bygdeforskning, Rapport 9. Trondheim.

Lambert, D.M., Cooper, M., and Pagh, J.D., (1998), Supply Chain Management: Implementation Issues and Research Opportunities. The International Journal of Logistics Management, 9(2), pp. 1-20.

Low, S.A. and Vogel, S., (2011), Direct and Intermediated Marketing of Local Foods in the United States. U.S. Department of Agriculture, Economic Research Service. Economic Research Report Number 128.

Magid, J., Granstedt, A., Dýrmundsson, O. Kahiluoto, H. and Ruissen, T., (2002), Urban Areas, Rural Areas and Recycling: The organic way forward? Danish Research Centre for Organic Farming (DARCOF), Report No. 3. Copenhagen.

Marsden, T., Banks, J. and Bristow, G., (2000), Food Supply Chain Approaches: Exploring their Role in Rural Development. Sociologia Ruralis, 40(4), pp. 424-438.

Martinez, S., Hand, M.; Da Pra, M, Pollack, S., Ralston, K., Smith, T., Vogel, S., Clark, S., Lohr, L., Low, S. and Newman, C., (2010), Local Food Systems Concepts, Impacts and Issues. Economic Research Report No. 97. United State Department of Agriculture, USA.

Parker, G., (2005), Sustainable food? Teikei, Co-operatives and Food Citizenship in Japan and the UK. Working Papers in Real Estate \& Planning, 11(05), pp. 1-29.
Roaldsen, I.H.E., (2009), Nisjematproduksjon i Norsk Landbruk -En Studie av Tilpasninger $i$ Verdikjeden. Nordlandsforskning, NF- arbeidsnotat nr. 1005. Bodø, Norway.

Roaldsen, I. and Ljunggren, E,. (2012), Thulefjord: En Nordnorsk Merkevare Produsert i Sфr-Norge? En faglig vurdering. Nordlandsforskning, Arbeidsnotat nr. 1001. Bodø, Norway.

Rusaanes, Å.M.H. and Hjortland, E., (2000), Handlingsplan for Norsk Matkultur. Statens Nærings- og Distriktsutviklingsfond, SND-rapport Nr. 1. Oslo.

Saunders, C., Barber, A. and Taylor, G., (2006), Food Miles: Comparative Energy/Emissions Performance of New Zealand's Agriculture Industry. Research Report No. 285. Lincoln University, New Zealand.

Thompson, J., (1967), Organizations in Action. McGrawHill, New York.

Vilko, J. and Ritala P. (2014), Service Supply Chain Risk Management. Operations and Supply Chain Management, 7(3), pp. 114-120.

Yin, R.K., (2003), Case Study Research, Design and Methods, Sage, Thousand Oaks CA.

Zepeda, L. and Leviten-Reid, C., (2004), Consumers Views on Local Food. Journal of Food Distribution Research, 35(3), pp. 1-6.

Zepeda, L. and Li, J., (2006), Who Buys Local Food? Journal of Food Distribution Research, 37(3), pp. 515.

Per Engelseth is associate professor at Molde University College since 2012. He received his Dr. Oecon degree from BI Norwegian School of Management in 2007. His main research interests include offshore maritime \& petroleum logistics, value chain management, complex responsive processes and agent-based modelling, lean networks, packaging logistics, CRM and ICT for logistics purposes, product standards and GS1 bar codes/labelling, food safety - quality - traceability. He has published numerous articles in academic journals as well as in anthologies including publications in International Journal of Physical Distribution and Logistics Management and Journal of Business and Industrial Marketing. This illustrates his scientific positioning in the borderline area of marketing and operations management. 